\title{
Mini Sharing Pemanfaatan Media Quiz Online bagi MGMP Guru Biologi Sidoarjo berbasis Edmodo
}

\section{Yuwono Marta Dinata ${ }^{1)}$, Hebert Adrianto ${ }^{2)}$, Hanna Tabita Hasianna Silitonga ${ }^{3)}$, Iman Pasu Marganda Hadiarto Purba ${ }^{4)}$}

Program Studi Informatika Universitas Ciputra Surabaya, Fakultas Kedokteran Universitas Ciputra Surabaya $^{1,2,3)}$ Program Studi Pendidikan Kewarganegaraan, Fakultas Ilmu Sosial dan Hukum, Universitas Negeri Surabaya ${ }^{4)}$

Universitas Ciputra, Citraland CBD Boulevard, Kota Surabaya ${ }^{1,2,3)}$, Jl. Ketintang No.i8, Ketintang, Kec. Gayungan, Kota Surabaya, Jawa Timur 60231 ${ }^{4}$

Email: yuwono.dinata@ciputra.ac.id

\begin{abstract}
ABSTRAK
Kegiatan mini sharing ini diselenggarakan oleh Fakultas Teknologi Informasi Universitas Ciputra Surabaya berkerjasama dengan Fakultas Kedokteran Universitas Ciputra dan Fakultas Ilmu Sosial dan Hukum Universitas Negeri Surabaya bertujuan untuk memberikan pelatihan penggunaan media online bagi guru Biologi kota Sidoarjo. Pelatihan ini dilakukan pada masa pandemi Covid-19. Pelatihan ini diberikan kepada kelompok Musyawarah Guru Mata Pelajaran (MGMP) khususnya mata pelajaran Biologi karena para Guru Biologi membutuhkan support penggunaan media online dalam pengajaran khususnya saat pandemi. Melalui kelompok MGMP ini dimaksudkan dapat menjangkau tidak hanya satu sekolah namun bisa lebih dari satu sehingga diharapkan dapat memberikan dampak lebih luas. Berdasarkan hasil diskusi terdapat guruguru yang belum terbiasa menggunakan media online khususnya dalam hal penilaian ujian melalui media kuis daring untuk siswa-siswinya. Setelah mengikuti mini sharing ini para guru dapat langsung mempraktekan ilmu yang didapatkan secara langsung karena pelatihan ini dilakukan menggunakan metode hands-on. Melalui mini sharing guru-guru menjadi mendapatkan alternatif untuk memanfaatkan teknologi yang tersedia salah satunya menggunakan Edmodo.
\end{abstract}

Kata kunci: covid-19, quiz online, Edmodo

\section{ABSTRACT}

This mini-sharing activity was organized by the Faculty of Information Technology, Ciputra University Surabaya in collaboration with the Faculty of Medicine, Ciputra University and the Faculty of Social Sciences and Law, State University of Surabaya. This training was conducted during the Covid-19 pandemic. This training is given to Musyawarah Guru Mata Pelajaran (MGMP) group, especially Biology subjects because Biology Teachers need support for the use of online media in teaching, especially during this pandemi. Through MGMP group this activity was intended to reach not only one school but more schools so that it is will be expected to have a wider impact. Based on the results of the discussion, there are teachers who are not used to using online media, especially in terms of assessments through online quiz media for their students. After participating in this mini sharing, the teachers can immediately put the knowledge they have learned because this training was done using the hands-on method. Through mini sharing, teachers can get alternatives to use technology, Edmodo.

Keywords: covid-19, quiz online, Edmodo 


\section{Pendahuluan}

Pemerintah telah mengambil beberapa tindakan untuk menangani pandemi Covid-19 (Wijaya et al., 2020). Dampak dari virus Covid-19 sangat besar karena hampir semua sektor kehidupan tidak bisa bergerak dan harus berhenti beraktifitas. Hal ini juga termasuk dalam dunia pendidikan. Kementerian Pendidikan Dan Kebudayaan telah mengeluarkan peraturan mulai dari surat edaran no 3 tentang pencegahan Coronavirus Disease (Covid-19) pada satuan Pendidikan bahwa memberikan instruksi bahwa perlunya menerapkan protokol kesehatan (Azhar et al., 2020), sesuai dengan peraturan Pelaksanaan Kebijakan Pendidikan dalam Masa Darurat Penyebaran Coronavirus Disease (COVID-19) Nomor 4 Tahun 2020 salah satu hal yang disampaikan bahwa proses belajar mengajar dilakukan secara jarak jauh atau dengan pembelajaran daring (Makarim, 2020), dan peraturan Pedoman Penyelenggaraan Belajar dari Rumah dalam Masa Darurat Penyebaran Corona Virus Disease (Covid-19) Nomor 15 Tahun 2020 (Kebudayaan, 2020). Maka dari itu beragam metode yang berbeda ditempuh dengan memanfaatkan internet sebagai media pembelajaran seperti platform elearning. Hal ini membuat manusia untuk segera melakukan adaptasi dalam sejarah peradaban manusia (Wijaya et al., 2020). Maka dari itu muncullah istilah blended learning dimana menggabungkan beberapa kuadran pembelajaran. Kuadran pembelajaran itu terdapat empat bagian sinkronous (tatap muka dan maya) dan sinkronous (kolaboratif dan mandiri). Guru dapat memilih dengan mengkombinasikan kuadaran yang ada seperti terlihat pada Gambar 1. Sehingga guru mendapatkan model pembelajaran blended learning disesuaikan dengan situasi dan kondisi dari tiap guru (Chaeruman, 2019).

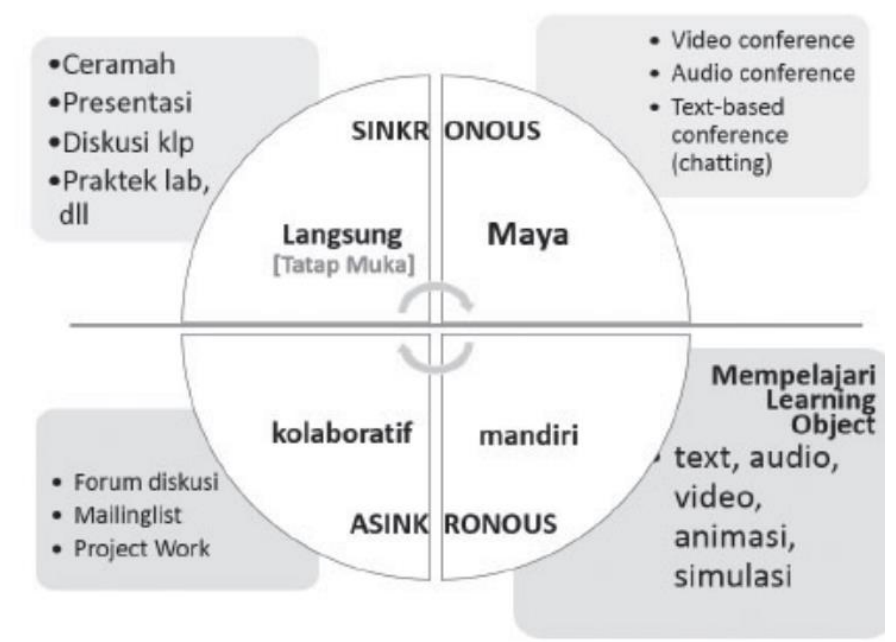

Gambar 1. Kuadran Pembelajaran Noord dalam Staley (Chaeruman, 2019)

Selain menetapkan model pembelajaran yang diperlukan untuk memberikan materi kepada siswa-siswinya guru perlu juga memikirkan faktor kesiapan e-learning. Faktor kesiapan e-learning (e-learning readiness) terdiri dari siswa, manajemen sekolah, guru, materi, sisi teknis, lingkungan, budaya sekolah and keuangan (Jamal, 2020; So, 2005). Dari delapan faktor kesiapan e-learning tersebut pihak kelompok MGMP mendahulukan dua faktor yang mendesak untuk disupport yaitu guru dan sisi teknis, hal ini akan dijelaskan lebih lanjut pada bagian hasil diskusi dengan kelompok MGMP.

Sebelum pada pandemi ini kami memang telah melakukan penjajakan kerjasama untuk pengabdian masyarakat. Pembahasan yang dilakukan adalah pemutahiran ilmu di bidang dunia Biologi saat ini dan penggunaan teknologi dalam pembelajran. Kerjasama telah dilakukan dengan membuat dan penandatangan MoU yang dapat dilihat pada Gambar 2. 


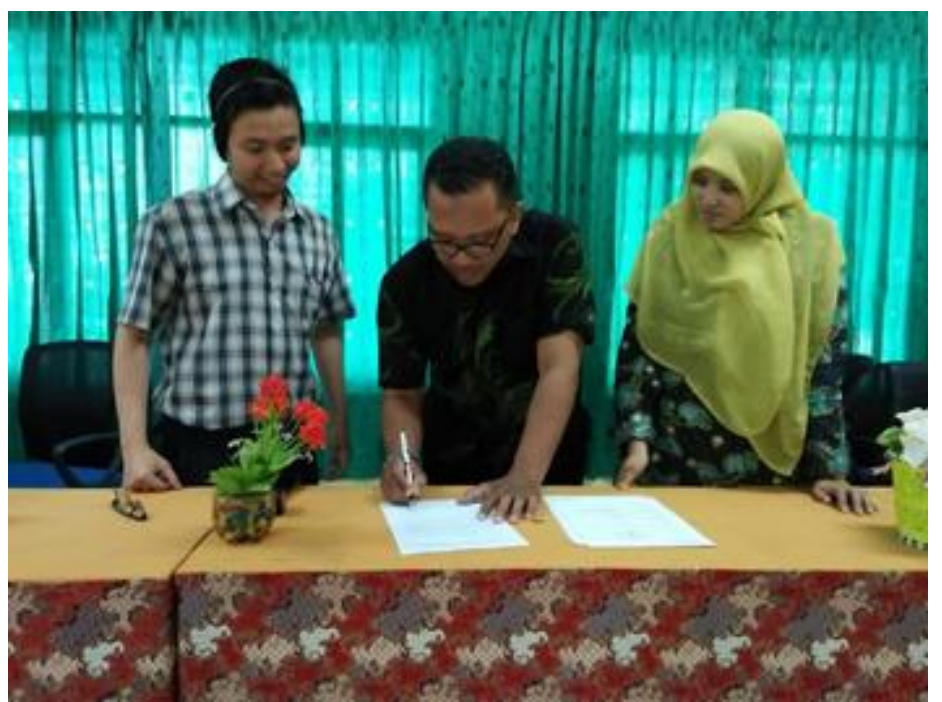

Gambar 2. Penandatangan perjanjian kerjasama pengabdian masyarakat

Kegiatan pengabdian masyarakat ini memiliki waktu yang saat tepat bagi mitra karena mitra sungguh membutuhkan support di saat pandemi ini. Diskusi dilakukan beberapa kali didapatkan bahwa mereka membutuhkan update perkembangan ilmu dalam dunia biologi dan penggunaan media pembelajaran online.

Oleh karena itu kegiatan mini sharing pemanfaatan media quiz online bagi MGMP guru Biologi Sidoarjo berbasis Edmodo perlu dilaksanakan. Kegiatan ini bertujuan untuk menambah wawasan baik guru maupun siswa mengenai ilmu terbaru dibidang Biologi dan guru sebagai fasilitator mendapatkan tambahan wawasan penggunaan perangkat baru sebagai salah satu metode untuk assesment ujian melalui onlie quiz. Kegiatan ini dilakukan dengan cara memberikan hands-on, sehingga para guru dapat langsung mempraktekkan. Kegiatan ini dimulai dengan memperkenalkan macam-macam platform pembelajaran salah satunya yang tidak berbayar adalah Edmodo. Setelah itu para guru akan membuat login di Edmodo dan langsung praktek untuk membuat materi maupun soal untuk assesmentnya. Melalui kegiatan ini diharapkan para guru tetap selalu siap untuk memberikan pembelajaran dan mengevaluasi para muridnya secara maksimal disaat pandemi.

\section{Tinjauan Pustaka}

\subsection{Media Pembelajaran}

Media adalah alat yang digunakan untuk menyampaikan atau menghantarkan pesan yang digunakan untuk pembelajaran (Rulviana, 2018). Media pembelajaran merupakan proses komunikasi yang dilakukan pada proses belajar mengajar. Proses komunikasi ini dapat dilakukan menggunakan alat bantu. Alat bantu yang dapat dilakukan untuk mengajar yaitu berupa visual gambar, model interaksi dsb (Hikmawan \& Sarino, 2018).

\subsection{Edmodo}

Edmodo merupakan salah satu e-learning yang berbasis cloud dan menyerupai media sosial seperti Facebook yang dapat digunakan sebagai media pembelajaran (Rulviana, 2018). Edmodo bisa digunakan sebagai platform yang dapat digunakan siswa, guru dan orang tua. Guru dapat memposting materi, nilai, tugas maupun untuk penilaian berupa kuis (Hikmawan \& Sarino, 2018; Rulviana, 2018), berikut ini tampilan muka halaman awal dari Edmodo dapat dilihat pada Gambar 3. 


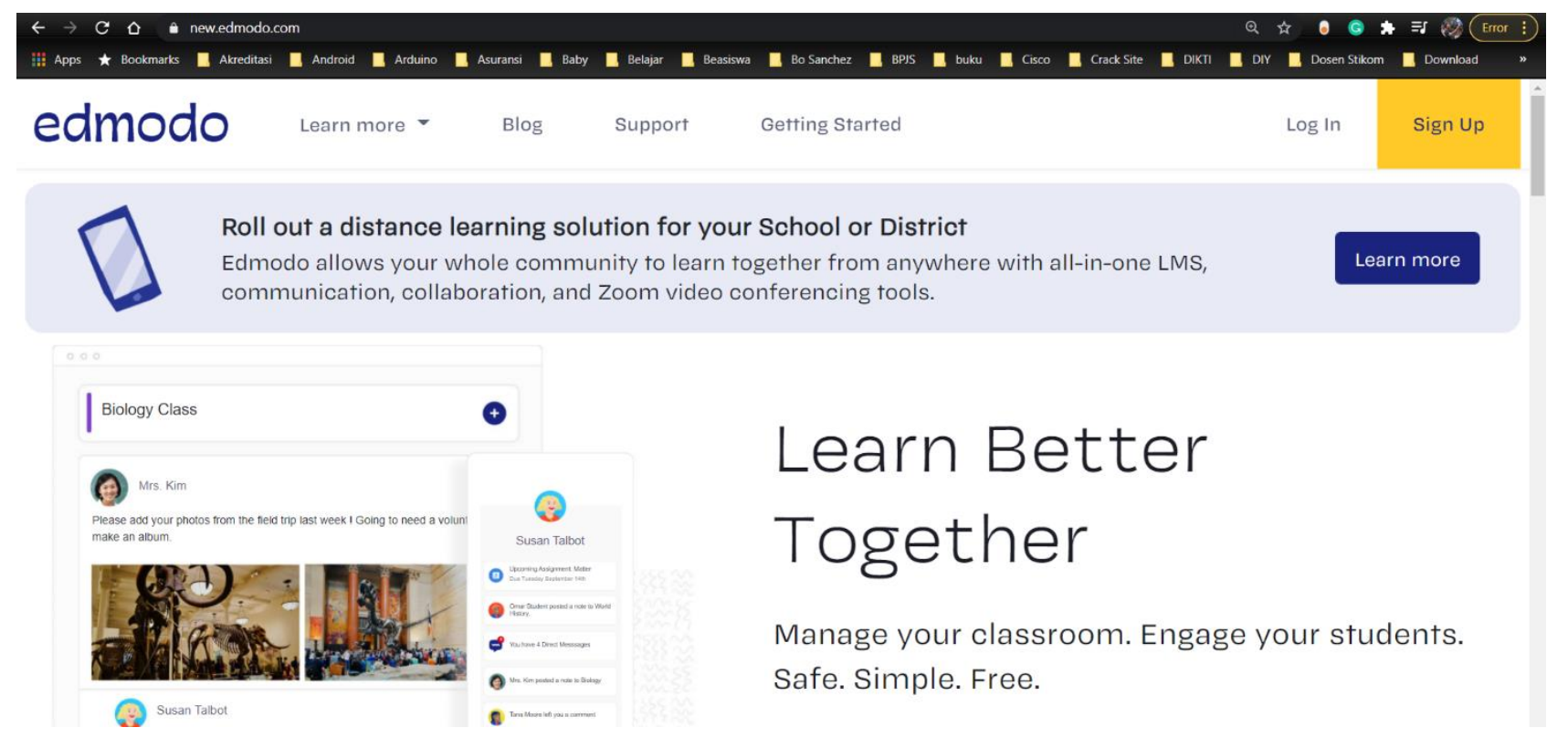

Gambar 3. Halaman awal Edmodo

\section{Metodologi Pelakasanaan}

Metode pelaksanaan abdimas ini dilakukan seperti alur yang dapat dilihat pada Gambar 4. Sebagai catatan kegiatan ini dilaksanakan pada saat pandemi Covid-19. Diskusi pada tahap awal ini dilakukan untuk mendapatkan hal-hal yang diperlukan oleh mitra. Hasilnya bahwa MGMP membutuhkan support untuk memperbaharui ilmu tentang Biologi dan kesiapan sumber daya dalam hal penggunaan teknologi untuk assessment. Untuk memperkuat kerjsama maka diadakan sesi untuk melakukan penandatangan kerjsama sehingga hal ini lebih mengikat kedua belah pihak dalam melaksanakan kerjasama.

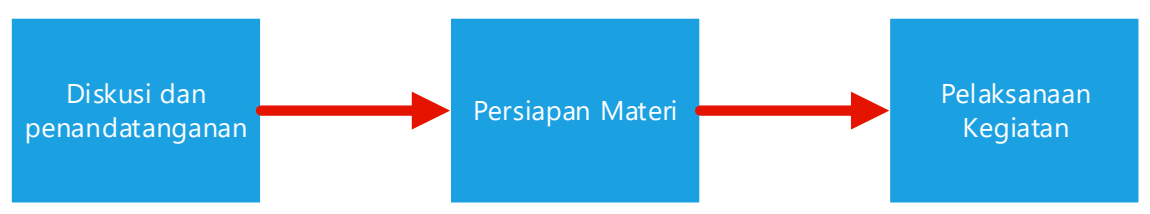

Gambar 4. Metodologi Penelitian

Atas dasar kerjasama dan menjawab kebutuhan tersebut, maka team Informatika Universitas Ciputra Surabaya dan Fakultas Kedokteran Universitas Surabaya serta Fakultas Ilmu Social dan Hukum Universitas Negeri Surabaya mengadakan Mini Sharing Pemanfaatan Media Quiz Online bagi MGMP Guru Biologi Sidoarjo berbasis Edmodo. Platform yang digunakan melakukan pelatihan adalah Edmodo. Edmodo ini dipilih karena dari sisi praktis dan tidak berbayar, serta pengguna Edmodo ini dari penjuru dunia dan cukup popular sebagai Learning Manajemen Sistem yang handal.

Persiapan materi dilakukan dengan terlebih dahulu membuat modul. Modul ini akan diberikan sehari sebelumnya dengan harapan para peserta dapat membaca terlebih dahulu. Sehingga hari $\mathrm{H}$ dapat langsung praktek. Modul yang dihasilkan sebanyak dua halaman dengan isi dimulai dari daftar di laman Edmodo, membuat kelas untuk menempatkan materi maupun tugas, membuat kuis dan memublikasikan kuis ke siswa.

Pelaksanaan kegiatan dilakukan pada 5 September 2020, dilakukan secara daring dihadiri oleh sekitar lima guru. Aktifitas dilakukan selama dua jam penuh. Kemudian setelah kelas peserta ada tugas yang perlu dilakukan dengan membuat kuis dan hasilnya disubmitkan ke group WhatsApp. Waktu dua jam ini cukup karena materi telah dibagikan sehari sebelumnya dan pada hari $\mathrm{H}$ peserta dapat mengikuti dengan mudah mecoba berbagai macam jenis soal, mulai dari pilihan ganda, memilih lebih dari satu jawaban, benar atau salah sampai memasukan gambar sebagai bahan kuisnya. 


\section{Hasil dan Pembahasan}

Kegiatan Mini Sharing Pemanfaatan Media Quiz Online bagi MGMP Guru Biologi Sidoarjo berbasis Edmodo yang bekerjasama antara Informatika Universitas Ciputra Surabaya dan Fakultas Kedokteran Universitas Surabaya serta Fakultas Ilmu Sosial dan Hukum Universitas Negeri Surabaya telah berhasil dilakukan pada 5 September 2020. Pelaksanaan kegiatan dilakukan secara daring dihadiri lima guru SMU Biologi seSidoarjo. Selama pelatihan yang menjadi kendala diawal adalah peserta masih baru dengan platform Edmodo sehingga butuh waktu untuk menyesuaikan, setelah beberapa saat para peserta sudah bisa menggunakan dengan baik. Kendala yang lain adalah koneksi internet yang sering putus. Namun hal ini tidak mengurangi minat para peserta untuk mengikuti pelatihan, bahkan saat mencoba mereka dengan antusias bertanya dan mencoba. Foto-foto kegiatan pelatihan dapat dilihat pada Gambar 5 dan Gambar 6.

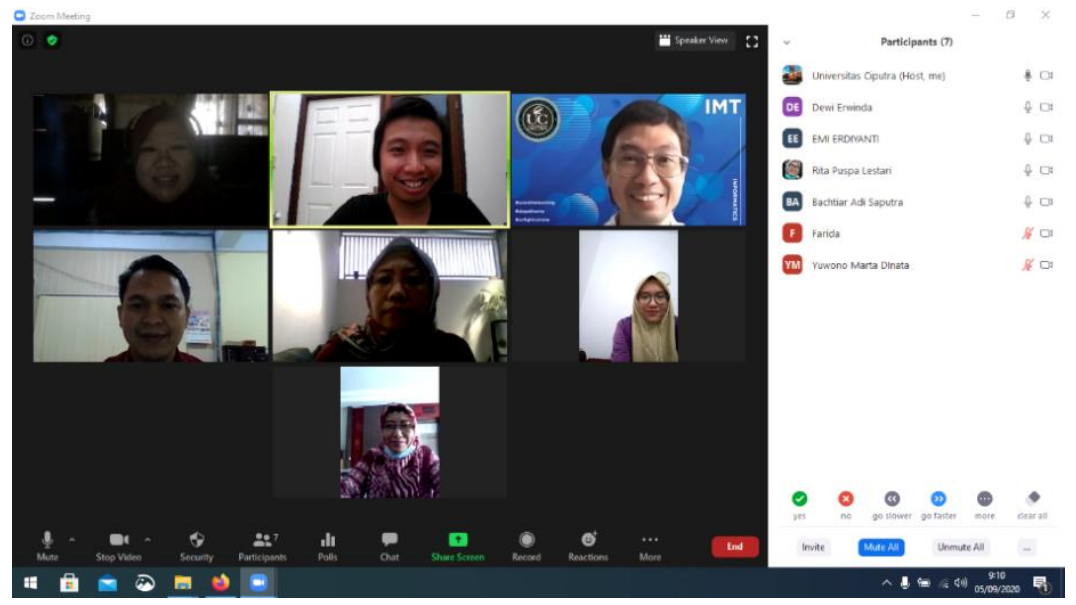

Gambar 5. Foto Zoom para peserta dan pembicara

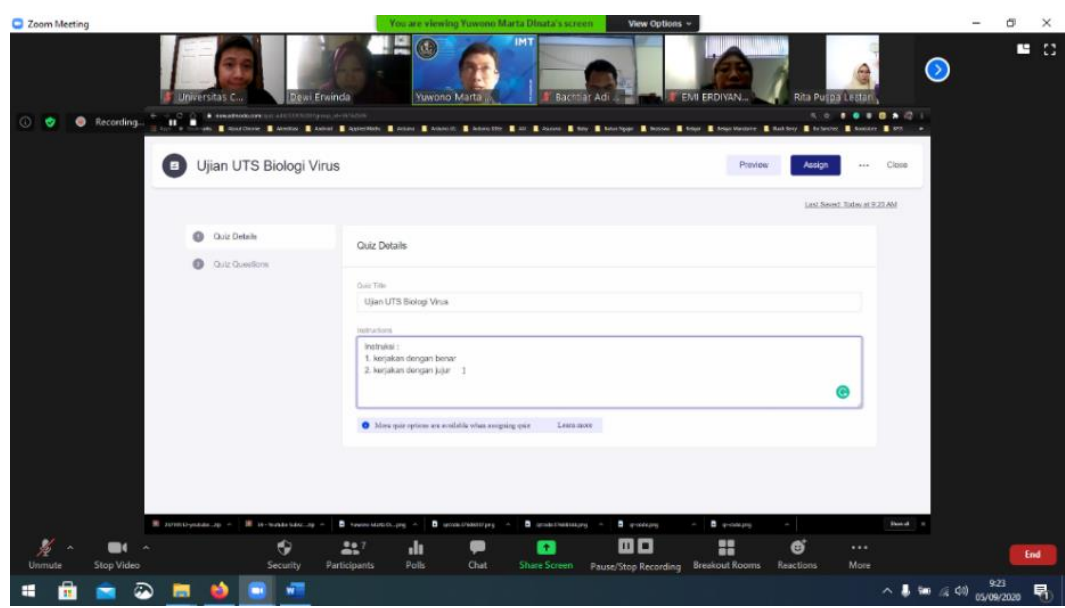

Gambar 6. Pemberian Materi Pembuatan kuis online

Narasumber menyampaikan materi mulai dari login hingga membuat kuis. Dimulai dari daftar dahulu di Edmodonya, kemudian setelah daftar peserta diminta untuk membuat kelas kemudian logout agar juga memahami jika sudah selesai melakukan aktifitas di Edmodo perlu logout karena untuk menjaga privasi tetap terjaga. Kemudian setelah berhasil masuk ke Edmodo maka dilanjutkan masuk ke bagian kelas yang telah di buat. Dikelas tersebut guru dapat memposting file pembelajaran ataupun video. Pada pelatihan kali ini akan fokus untuk pembuatan kuis. Pada pembuatan kuis ini terdapat alternatif jenis pertanyaan mulai dari pilihan ganda, pilihan yang bisa lebih dari satu, benar 
atau salah dan mensetting soal secara random beserta jawabannya. Pengaturan secara random ini digunakan meminimalisir kerjasama antara siswa.

Modul yang telah dikirim sehari sebelumnya dapat dimanfaatkan para peserta untuk dibaca kembali agar lebih paham. Modul tersebut terdiri dari dua belas halaman yang sudah cukup ringkas. Narasumber memang mencoba menampilkan yang hal-hal yang penting sesuai yang peserta butuhkan, tampilan modul halaman pertama dapat dilihat pada Gambar 7

Abdimas dgn SEL untuk guru Biologi

\section{Pemanfaatan LMS Edmodo sebagai penyampaian Soal Online pada masa pandemi Covid-19}

Pada kesempatan workshop kali ini akan membahas pemanfaatan online learning management system (LMS). LMS yang secara online banyak sekali salah satunya adalah Edmodo. Edmodo merupakan platform untuk menyampaikan materi yang mudah diatur dan engagement dengan student bias lebih mudah. Edmodo ini bias digunakan dengan mudah dan cepat, dapat menghubungkan antara guru, orangtua dan anak. Edmodo selain melalui web juga bisa diakses melalui aplikasi mobile termasuk IOS, Android dan Windows Phone. Melalui Edmodo, guru bias membuat kelas virtual, dapat juga mencari dan membagikan hasil pengajarannya yang bagus dan bergabung ke komunitas pembelajaran yang luas. Edmodo juga terdapat fasilitas untuk orang tua dapat memantau perkembangan anaknya secara online. Edmodo saat ini sudah memiliki tampilan yang lebih segar alias sudah diperbaiki, seperti tampak pada Gambar 1.

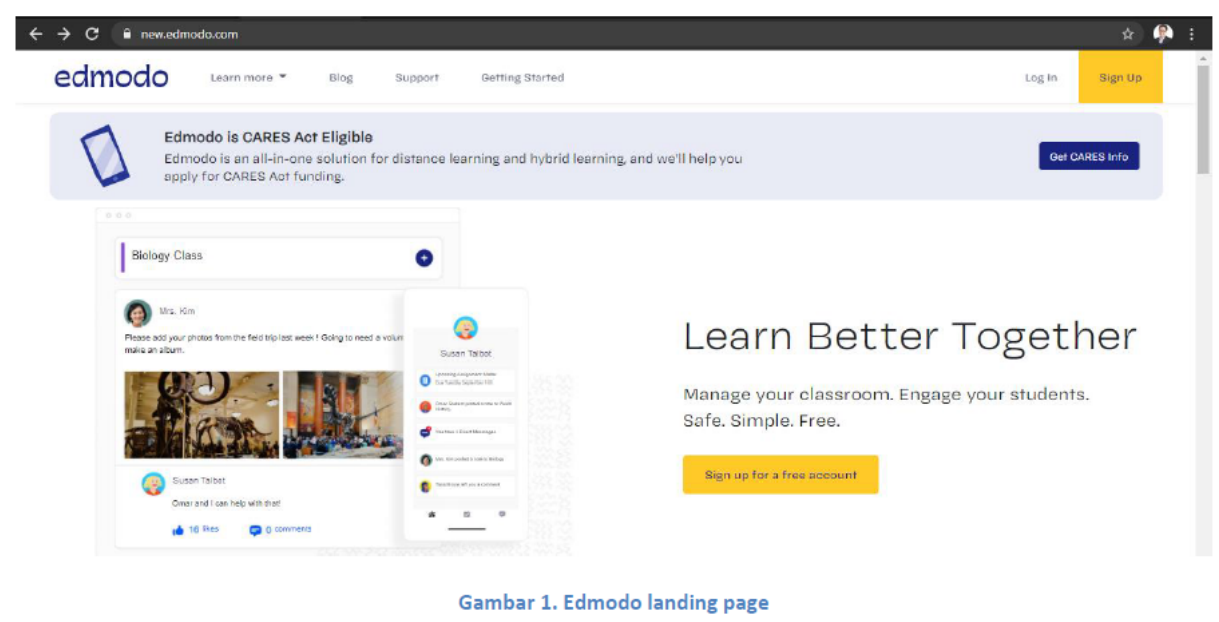

Pada workshop kali ini akan dipandu untuk memulai menggunakan Edmodo dari awal sampai memposting materi, membuat tugas dan melakukan penilaian.

Gambar 7. Halaman pertama modul pelatihan

Antusiasme dari para peserta sangat bagus dan sangat serius mengikuti dengan bukti tugas-tugas yang diberikan disampaikan setelah pelatihan. Tugas yang diberikan adalah membuat soal sesuai dengan bidang yang telah dikuasai yaitu tentang Biologi, contoh-contoh hasil pelatihan dapat dilihat pada Gambar 8. 


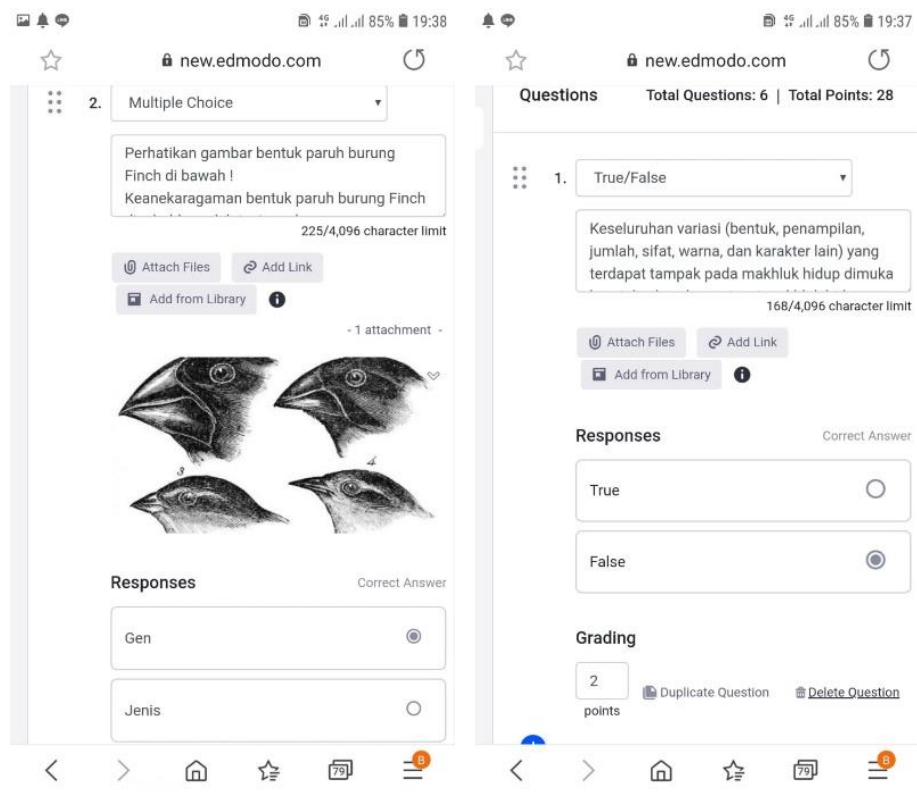

Gambar 8. Hasil tugas yang diberikan.

Kegiatan Mini Sharing Pemanfaatan Media Kuis Daring bagi MGMP Guru Biologi Sidoarjo berbasis Edmodo yang bekerjasama antara Informatika Universitas Ciputra Surabaya dan Fakultas Kedokteran Universitas Surabaya serta Fakultas Ilmu Sosial dan Hukum Universitas Negeri Surabaya telah berhasil dilakukan pada 5 September 2020. Para pesertapun antusias dan semoga melalui kegiatan ini para Guru Biologi seSidoarjo dapat memanfaatkan media pembelajaran online dengan maksimal.

\section{Daftar Pustaka}

Azhar, E. I., Hui, D. S. C., Memish, Z. A., Drosten, C., Zumla, A., \& Kemdikbud RI. (2020). Edaran Tentang Pencegahan Wabah COVID-19 di Lingkungan Satuan Pendidikan Seluruh Indonesia. Infect Dis Clin North Am, 33, 1-5.

Chaeruman, U. A. (2019). Merancang Model Blended Learning Designing Blended Learning Model. Jurnal Teknodik, 17(4), 053. https://doi.org/10.32550/teknodik.v17i4.577

Hikmawan, T., \& Sarino, A. (2018). Pemanfaatan Media Pembelajaran Berbasis Edmodo Terhadap Motivasi Belajar Siswa Sekolah Menengah Kejuruan. Jurnal Pendidikan Manajemen Perkantoran, 3(1), 226. https://doi.org/10.17509/jpm.v3i1.9459

Jamal, S. (2020). Analisis Kesiapan Pembelajaran E-Learning Saat Pandemi Covid-19 Di Smk Negeri 1 Tambelangan. Jurnal Nalar Pendidikan, 8(1), 16. https://doi.org/10.26858/jnp.v8i1.13561 Kebudayaan, K. P. D. (2020). Pedoman Penyelenggaraan Belajar Dari Rumah Dalam Masa Darurat Penyebaran Corona Virus Disease (Covid-19). Surat Edaran Nomor 15 Tahun 2O2O, (021), $1-20$.

Makarim, N. A. (2020). Surat Edaran Nomor 4 Tahun 2020 Tentang Pelaksanaan Kebijakan Pendidikan Dalam Masa Darurat Penyebaran Coronavirus Disease (COVID-19). Jakarta.

Rulviana, V. (2018). Implementasi Media Edmodo Dalam Mata Kuliah Pengembangan Kurikulum Sekolah Dasar. Refleksi Edukatika: Jurnal Ilmiah Kependidikan, 8(2). https://doi.org/10.24176/re.v8i2.2361

So, K. K. T. (2005). The e-learning readiness of teachers in Hong Kong. Proceedings - 5th IEEE International Conference on Advanced Learning Technologies, ICALT 2005, 2005, 806808. https://doi.org/10.1109/ICALT.2005.266

Wijaya, R., Lukman, M., \& Yadewani, D. (2020). Dampak Pandemi Covid-19 Terhadap Pemanfaatan E-Learning. Dimensi, 9(2), 307-322. 